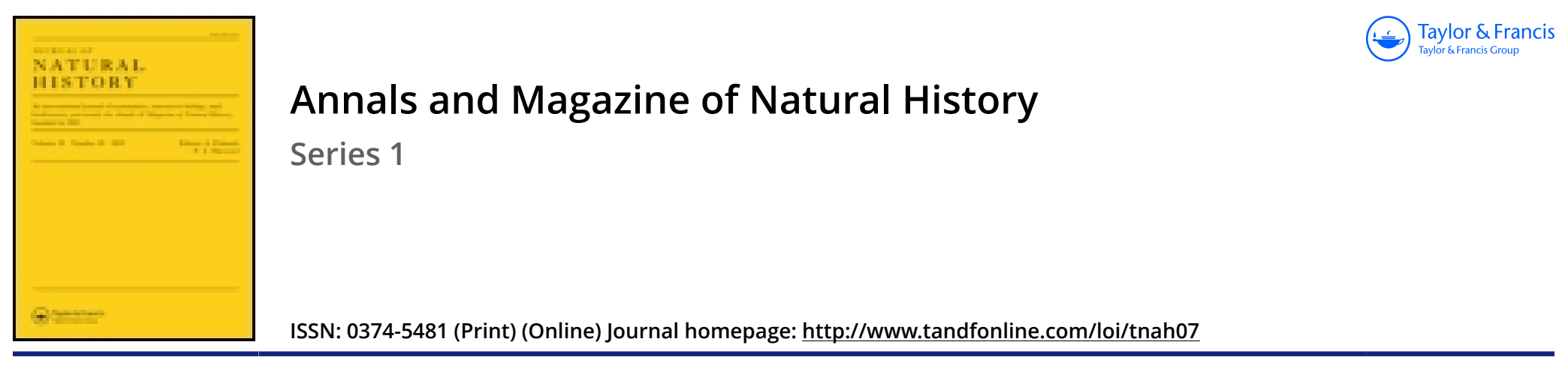

\title{
XI.-On two new species of British Jungermasnniæ
}

\section{Thomas Taylor M.D.}

To cite this article: Thomas Taylor M.D. (1843) XI._-On two new species of British Jungermasnniæ, Annals and Magazine of Natural History, 12:75, 88-90, DOI: 10.1080/03745484309442492

To link to this article: http://dx.doi.org/10.1080/03745484309442492

曲 Published online: 04 Dec 2009.

Submit your article to this journal $\asymp$

Q View related articles $₫$ 
compose, assimilate and remove from the fair face of Nature, and hence they liave carned the not inappropriate, though inclegant, appellation of "Nature's scavengers." This however is taking but a very limited view of the powers and operation of fungi, since the present inquiry proves that they have the ability to invade and destroy the living vegetable fabric, and perhaps animal too; and this not merely while the vegetable is in a living state, but while the functions of its life are in full and licalthy operation. Thus, in the operation of the fungi, as in most things, there is, as regards man's welfare, a mixture of good and cvil, of benefit and disservice; the good result accruing to man, howerer, far outbalancing the evil.

Inquirics such as the present are peculiarly interesting, not mercly from their valuc in a scientific point of vicw, but from the hope which they carry with them, amounting in this case almost to a conviction, that ultimately they will be attended with practical results. I hope that at no distant day a remedy will be found for some of the evils occasionally resulting to the vergetable world through the instrunicntality of fungi.

XI.-On two new species of Brilish Jungermannic. By'l'Homas TAYLoR, M.D., Dunkerron, Kcnuare*.

Jungermanis ripris, MSS. T. T. Caule procumbente, subramoso; foliis subapproximatis, amplexicaulibus, oblongo-orbiculatis, concavis, integerrimis : fructu terminali ; calycibus obovatis, apice plicatis.

Jung. pumila, Lind. Syn. Hep. p. 69. t. 2. (nec Witheringii).

Ad rivulorum umbrosorum rijas saxosas Hibernix, Britannix atque Germania.

Caules procumbentes ramosi, subimplexi atque subcespitosi, 1-2 unciales, luride virides. Folia subimbricata, basi amplexicaulia, concava subrotunda aut parum elongata, patula, integerrima, cellulis ma. joribus. Perichatialia majora, calycis dimidium inferius tegentia. Calyces obovati seu oblongi, juniores etiam obtusi, apice plicati, plicis sæpius octo. Pedicellus semiuncialis. Capsula oblonga, quadrivalvis. Perigonia in rami medio sita vidi, ex foliis paucis, adpressis, basi ventricosis, antheram solitariam tenentibus conflata.

It is probable that the present species is extremely common, and that it has long been confounded by others, as well as certainly by myself, with Jung. pumila, With. The specimen collected by me in the river Dayle in 1813, and quoted under $J . p u$ mila in 'The British Jungermannix,' belongs to the present. It has been gathered long ago and carefully laid aside for further cxamination by $\mathrm{D}_{r}$. Greville: his specimens are from Breadalbanc. $\Lambda$ gain, Mr. William Wilson found the plant ncar Bangor Ferry in

* Rcad before the Botanical Socicty of Ediuburgh. 
Wales, Mr. G. J. Lyon at Campsie, and Mr. Spruce at Eskdale; lately I have seen it at Blackwater Bridge and at Turk Watcrfall, both in the county of Kerry. Lindenberg too secms to have referred the present to Jung. pumila, With., from which the following marks will sufficiently distinguish it: 1 . the paler colour; 2. the larger size; 3 . the leaves more distant, amplexicaul, more concave, broader and rounder ; 4 . their cells much larger; 5 . the calyx less exserted out of the perichatium ; 6 . the calyx never acuminated, as is constant and characteristic in Jung. pumila, With.; 7. the calyx distinctly plicate above. From Jung. spharocarpa, Hook., the present differs, - 1 . by the larger and more procumbent stems; 2 . the calyx plicate above, longer and less wide; 3 . the leaves not cxactly orbicular, but rather terminating in the figure of a parabola. The present species approaches to Jung. autumnalis, DeCandolle, which has becn found not only on the continent of Europe but likewise in North America, and which may be confidently looked for in the British Isles, where, howerer, it has hitherto been unnoticed. In Jung. aulumnalis, DeCand., l. stipules are prescnt, especially about the terminations of the young branches; 2 . the leaves liave a morc vertical position, and are nore alpressed to the stem ; 3. their colour is rufescent, and 4. they are distinetly marginated.

Jungermannis reclusa, MSS. T. T'. Caule repente, implexo, subpinnato ; foliis approximatis, semirerticalibus, rotundato-quadratis, bifidis, perichatialibus majoribus erectis; fructu ramulo proprio insidente; calyce cylindracco-ovato, apice acuminato subtrigono, ore denticulato; capsula ovata.

In cryptis ericetorum Boream spectantibus, humidis, sxpius occurrit prope Dunkerron, Hibernix.

Cespites lati, tenues seu supcrficiales, fuscescentes, cx quibus calycum apices plurimi, albidi, sparsim surgunt. Caules filiformes, sub. flexuosi, subpinnati. Folia heteromalla, minutissima, magnitudine folia Jung. byssacec Roth. vix excedentia, latissima, ovata, bifida, scu potius alte cmarginata, laciniis conniventibus, cellulis discretis, minoribus. Stipula nulla. Calyces ore albidi, subtrigoni, cminentes, acutiusculi, dentati.

It is very possible that Lindenberg's var. $b$. of Jung. bicuspidata, $\mathbf{L}$., is the sanc as our plant, if we may judge from the scanty description, but the specics differ by numerous minute yet constant marks. Jung. reclusa is, 1 . of much smaller sizc, approaching in this respect to Jung. lyssacea, Roth. ; 2. the leaves are shorter than in J. bicuspidata, L.; 3 . they are more opake; 4. more concave; 5. their shallower emargination is more rounded; 6 . they are more crowded; 7 . they point to one side, viz. upwards; 8 . they are rotumdato-ovate; 9 . their cells are more minute, and yet separated from cach other by larger vessels; 10 . the perichatium is shorter, and its leaves less acuminated; 11. the stens are wider 
in proportion to the learcs; 12 . the colour of the plant is clarker, and when fresh of an olive-green ; 13. the growth is more tufted; 14. the calyx, though absolutcly less than in Jung. bicuspidata, $\mathrm{L}$., yet, relatively to the size of its own leaves and stems, is grenter and more clongated; 15 . the calys is narrower above; 16. the capsule is far shorter in figure and quite chnracteristic; 17 . the gemma are smooth, ncrer angular, nind situated on clusters of leaves and not on a nakcd cupitulus. It only remains to add, that our plant differs from Jung. connivens, 1)icks., by smaller size, much minuter reticulation, by the leaves not being decurrent, by its subpinnate habit, to say nothing of the less tumid and morc acuminatcd calys.

$\Lambda_{\text {pril } 18,1843 .}$

XII.-List of Birds obtained in the vicinity of Calcutta, from $S_{(p)-}$ tember 1811 to March 18.13 inclusive. 13y lidward 13LYTH, Curator to the Muscum of the Asiatic Socicty of Bengal.

1. Palcornis Alcxandrimus; P. Nipalensis, Hodgson, 'As. Res.' xix. 177. A hill specics, not usually met with in the low country, but has occasionally been observed in the Calcutta Botanic Garden.

2. P. torquatus. Very abundant, in flocks of from two or threc to twenty. I have seen a pair alight and walk about on the parapet of a housc. Flight rapid, and their screaming cry is frequently emitted on the wing, announcing their approach.

3. $P$. Bengalensis. 'This beautiful sjecics is much less common than the last, though still not rare. It is also lcss noisy, and I have always observed it in small flocks.

4. P. Pondicerianus. This fourth Bengalese species is almost exclusively confined to the hills, but is brought in tolcrable abundance to the Calcutta shops. It has not becn ouscred by Mir. Jerdon in the peninsula of India, though named I'ondicerianus; but it is plentiful on the opposite coast of the Bay of Bengal, and as I saw numerous parrots of this genus flying across the bay, when making for Madras, it might be inferred that the same species inhabit both coasts; though perhaps this may apply only to $P$. torquatus and $P$. Bengalensis, which are frequent in the plain country*.

* 'Tlue only arlditional species of this genus known to me, except the $\Lambda \mathrm{u}$ stralian (so-called) P. Marrahandl, are, in India, P. schisticeps, Hodgson, ' $\Lambda$ s. Res.' xix. 178, peculiar to the Himalaya, and $P$. columboides, Vigors, on the Ncilghicries : the Malay countries produce $P$. Malaccensis; and I lave just received a female specimen from the Mauritius, which is probably refurable to $P$ s. bitorquatus, Finhl : $P$. xanthosoutus, Bechstcin, said to inlabit 'lernate, rests on the authority of a description by Levaillant, wha saw a living specimen. 'The remaining described species in Mr. Vigor's's Monograph of this genus ('Lool. Journ, ii. $49 \mathrm{ct}$ seg.) are merely nominal. Closcly allied to Palciornis is my genns Psillints (Journ. As. Soc. Beng. xi. 789), founded on the P'sitfacus DIalaccensis, Lathan, not of Gmelin, and apparently comprising the remakable P's. scturius of 'T'mminck,-E. I3. 